\title{
Sensitivity of spaceborne radar to near-surface soil moisture in grasslands across southern Ireland
}

\author{
Authors: \\ Brian Barrett (corresponding author) \\ School of Geography and Archaeology \\ University College Cork (UCC) \\ Cork, \\ Ireland \\ Email: bbarrett@ucc.ie \\ Tel: 00353868781556
}

\section{Ned Dwyer}

Coastal \& Marine Resources Centre (CMRC),

University College Cork (UCC),

Irish Naval Base, Haulbowline,

Co. Cork,

Ireland

\section{Pádraig Whelan}

School of Biological, Earth and Environmental Sciences,

University College Cork (UCC),

Butler Building,

Distillery Fields, North Mall,

Cork,

Ireland 


\section{Sensitivity of spaceborne radar to near-surface soil moisture in grasslands across southern Ireland}

The amount of water stored in the soil is a key parameter for the energy and mass fluxes at the land surface and is of fundamental importance to many agricultural, meteorological, biological and biogeochemical processes. This study investigates the potential of retrieving surface soil moisture in grassland areas from a time series of 68 ENVISAT Advanced Synthetic Aperture Radar (ASAR) Wide Swath Mode (WSM) scenes, acquired between 2007 and 2009, using an empirical regression approach. WSM data enables larger areas to be observed with a higher temporal sampling capability, compared to Image Mode (IM) data, and provide an appropriate spatial resolution for regional applications. As expected, the radar backscatter signal was found to increase with increasing soil moisture. Interseasonal analysis showed that the VV (Vertical transmit-Vertical receive) polarisation radar signal is more sensitive to surface soil moisture during the spring and autumn months, where average signal increases of about $4 \mathrm{~dB}$ corresponding to relative soil moisture increases of $\sim 40 \%$ were obtained. Results also display significant $(\mathrm{p}<0.05)$ correlations between the $\mathrm{HH}$ (Horizontal transmit - Horizontal receive) polarisation signal and surface soil moisture, with $r^{2}$ values ranging from $0.67-0.86$ for some of the test sites. Overall, the results suggest that the use of an empirical linear relationship approach is a good approximation of the relationship between ASAR WSM backscatter coefficients and surface soil moisture over grassland areas.

Keywords: Radar, soil moisture, grasslands, empirical regressions, in situ measurements

\section{Introduction}

Measurements of surface soil moisture are needed to improve the understanding of local and regional water cycles, ecosystem dynamics and, through its control on evaporation and plant transpiration, the many processes that link the water, energy and carbon cycles (Teuling and Troch 2005, Brocca et al. 2010). Furthermore, a thorough understanding of soil moisture behaviour would facilitate effective flood and drought forecasting, improved weather prediction and to a larger extent, global climate change research (Entekhabi et al. 1996).

Soil moisture dynamics is dependent on both meteorological conditions and soil physical characteristics and, as a result, exhibits large spatial and temporal variations between different areas, seasons and years (Schulte et al. 2005). The spatial and temporal coverage attainable by spaceborne Synthetic Aperture Radars (SARs) makes them a promising approach for measuring short-term, seasonal and long-term variations 
in surface soil moisture (Baghdadi et al. 2008). In the past 30 years, several different approaches to derive soil moisture from spaceborne active microwave measurements have been investigated (Barrett et al. 2009). The most common techniques employed are empirical/semi-empirical (e.g. Dubois et al. (1995), Wickel et al. (2001), Oh et al. (2002), Zribi and Dechambre (2002)) and theoretical models (e.g. Fung et al. (1992), Altese et al. (1996), Song et al. (2009)) to determine the relationship between the radar signal and volumetric soil moisture. The main advantage of empirical backscatter models over theoretical models is that many natural surfaces do not fall into the validity ranges of the theoretical models and the number of input parameters required usually makes the model's implementation extremely complex (Walker and Houser 2004).

For multi-temporal soil moisture monitoring, the spatial coverage and temporal resolution of fine-scale SAR observations can be relatively low, usually due to either sensor limitations (e.g. satellite repeat cycle) or user conflicts in the case of multi-mode SAR sensors (e.g. ASAR, PALSAR, RADARSAT) (Van der Velde et al. 2008). The medium resolution ASAR Wide Swath mode (Desnos et al. 2000) on the other hand, has a wider swath $(405 \mathrm{~km})$ than higher resolution modes (e.g. Image mode) and provides shorter revisit intervals ( 3 - 5 days compared to 35 days for Image mode). The focus of this study was to investigate the influence of surface soil moisture on backscatter signatures from VV (Vertical transmit-Vertical receive) and HH (Horizontal transmit - Horizontal receive) polarisation medium resolution ASAR WSM data in seven grassland study sites in the south of Ireland. The study concentrated on grassland, as almost $80 \%$ of the agricultural area of Ireland (4.4 million hectares) is devoted to grass (Teagasc 2010). This represents approximately 50\% of the total land area of Ireland (6.9 million hectares).

\section{Description of Study Sites}

The research was carried out in seven homogeneous grassland (permanent pasture) sites located in the south of Ireland namely, Ballinhassig, Carraig na bhFear, Clonakilty, Donoughmore, Kilworth, Pallaskenry and Solohead. All seven sites are typically low lying (ranging from a minimum altitude of $15 \mathrm{~m}$ to a maximum $104 \mathrm{~m}$ above sea level) and relatively flat (slope $<6^{\circ}$ ) with a loamy soil texture. Figure 1 shows the geographic location of each of the study sites (marked by yellow triangles) and three Met Éireann (Irish Meteorological Service) stations (red circles). The area has a temperate climate and generally high relative humidity, averaging $~ 90 \%$ throughout the year. Annual precipitation recorded at each of the study sites is given in table 1. Due to a suspected instrument fault, no value is included for Carraig na bhFear in 2009. Overall, 2009 was the wetter year in which November is notable for the high rainfall recorded across all stations. An increasing annual precipitation is observed, considering the long-term annual average rainfall (1961-1990) recorded for three nearby Met Éireann climatological stations (1207mm, 935mm and 926mm for Cork Airport, Roches Point, and Shannon Airport respectively).

Figure 1. 
Table 1.

\section{Data and Methods}

\subsection{Ground Measurements}

Campbell Scientific CS616 water content reflectometers (Campbell Scientific 2004), installed at a depth of $5 \mathrm{~cm}$ below surface at each of the study sites under the framework of the Aeon project (http://aeon.ucc.ie/), were used for the continuous measurement of soil moisture content. Measurements were recorded at 30 minute intervals from a single point at each study site and are expressed in volumetric water content $\left(\mathrm{m}^{3} / \mathrm{m}^{-3}\right)$. The CS616 sensor is a frequency domain reflectometer (FDR) that uses high frequency pulses travelling back and forth along a $30 \mathrm{~cm}$ two-rod probe installed horizontally into the ground to estimate the permittivity of the soil. The sensors were calibrated using soil moisture measurements obtained through gravimetric sampling and have an accuracy of $+/-2.5 \%$ and a probe-to-probe variability of $+/-1.5 \%$. Precipitation and soil temperature were also recorded at each of the test sites at 30 minute intervals. The surface soil moisture at the time of image acquisition (both VV and $\mathrm{HH}$ polarisations) displayed in figure 2, shows that, for both years, between November and April, levels approach near saturation and gradually decrease to a minimum in June. However, between June and November 2008 there was a steady increase in the surface soil moisture while it remained relatively uniform for the same period in 2009, with a sudden large increase in October 2009. The values vary between study sites but all display, more or less, the same general trend in increases and decreases. The large spikes in the Ballinhassig dataset around April 2009 may have been caused from a localised buildup of surface water.

Figure 2.

An analysis of the time-series plots of measured soil moisture reveals distinct soil moisture phases, similar to those observed by Illston et al. (2004). The November to March period generally has the highest soil moisture levels, as a result of inactive vegetation and minimal evapotranspiration. Soils dry between March and July as a result of increasing surface temperature, evapotranspiration and decreasing precipitation. Soil evaporation decreases from July to November due to decreased sun angles in addition to vegetation biomass decreases and precipitation increases, which results in increasing soil moisture levels.

\subsection{SAR data Acquisition and Processing}

ENVISAT was launched on the $1^{\text {st }}$ March 2002 by the European Space Agency (ESA) and operated successfully until the end of its mission on $8^{\text {th }}$ April 2012. The onboard Advanced Synthetic Aperture Radar (ASAR) instrument, operating at C-band (5.3 
$\mathrm{GHz}$ ), was capable of operating in multiple modes (Stripmap- Image and Wave modes; and ScanSAR-Alternating polarisation, Wide Swath, and Global Monitoring modes) at various incidence angles in several polarisations. The satellite passes the descending node at 11:00 am UTC and the ascending node at 22:00 pm UTC. In this research, the emphasis is on the Wide Swath mode data. Sixty-eight ASAR WSM data acquisitions were acquired over the study sites between $11^{\text {th }}$ Nov 2007 and $4^{\text {th }}$ Dec 2009. The SAR data were delivered as ASA_WSM_1P data products from the European Space Agency (ESA) and processed and calibrated using SARscape ${ }^{\circledR}$ software within an ENVI® environment. The dataset consists of 7 scenes in $\mathrm{HH}$ polarisation ( 3 ascending and 4 descending) and 61 scenes in VV polarisation (8 ascending and 53 descending) (see Appendix 1). Both $\mathrm{HH}$ and $\mathrm{VV}$ datasets were analysed separately.

Auxiliary orbit and calibration information for each image was used to generate the most accurate output backscattering coefficients $\left(\sigma^{0}\right)$. The most recent external calibration files (XCA) along with precise satellite orbital data (VOR) provided by the DORIS (Doppler Orbitography and Radiopositioning Integrated by Satellite) instrument onboard ENVISAT were used. The WSM data were multi-looked by a factor of 3 in azimuth and 7 in range to produce 21-look images (quasi-square pixels of $150 \mathrm{~m} \mathrm{x}$ $150 \mathrm{~m})$ and no further speckle filtering was carried out. Since WSM data use ScanSAR technology to cover a much larger swath-width, effects on the backscatter due to the varying incidence angle and distance from the sensor are present in the scene. Previous studies have found that low to medium incidence angles are best for soil moisture estimation (Srivastava et al. 2003, Baghdadi et al. 2006). To limit the influence of the large incidence angle $\left(17^{\circ}-42^{\circ}\right)$ range and to ensure inter-comparability between the different data scenes, an angular normalisation to an incidence angle of $30^{\circ}$ was applied based on a modified cosine model (Ulaby and Dobson, 1989). The images were subsequently geometrically and radiometrically calibrated. A 90m SRTM (Shuttle Radar Topography Mission) digital elevation model was used to geocode the images into the Irish National Grid projection using a Range-Doppler approach. Polygons of $5 \times 5$ pixels centred on the study site location were used to calculate the mean backscattering coefficient at each study area for all acquisition dates. Finally, mean backscatter values were then converted to decibel $(\mathrm{dB})$ units $\left(\sigma^{0}\right)$ for analysis with ground measurements.

\subsection{Methodology}

Vegetation cover attenuates the backscattered signal and therefore decreases the sensitivity of the radar backscatter to soil moisture (Ulaby et al. 1986). Some studies (e.g. Loew et al. (2006), Zribi et al. (2005), and Van Doninck et al. (2012)) have presented methodologies to correct backscatter measurements for these effects. However, it has been found in various studies that sparse or low vegetation cover has little influence on the backscattered signal and can generally be neglected. For example, Dobson et al. (1992) found that a grass cover (average height of $40 \mathrm{~cm}$ ) had little influence on ERS-1 (VV polarisation) backscattering coefficients, attenuating the signal by less than $0.2 \mathrm{~dB}$. As all the study sites were cultivated with relatively short grass (average height $<30 \mathrm{~cm}$ ), the influence of the vegetation cover is not considered in this study. Similarly, for each of the test sites, the surface roughness was assumed to be 
constant throughout the study period, as in Wagner and Scipal (2000), Baup et al. (2007), and Van der Velde et al. (2008). Under these assumptions, the backscatter coefficient can be considered to be linearly related to the soil moisture (Ulaby et al. 1982, Cognard et al. 1995, Quesney et al. 2000). Regression analysis was performed to investigate the relationship between in situ soil moisture measurements and backscatter coefficients in both VV and $\mathrm{HH}$ polarisations. All statistical analyses were performed using PASW/SPSS ${ }^{\circledR} 17$ software.

\section{Results and Discussion}

\subsection{Backscatter Signature Analysis}

Soil moisture variations usually follow precipitation trends, however they are difficult to determine or predict due to the complex interactions between the different factors affecting the moisture content of a soil (e.g. topography, vegetation cover, soil type) (Hawley et al. 1983, Famiglietti et al. 1999, Daly and Porporato 2005, Tromp-van Meerveld and McDonnell 2006). Daily precipitation data from November 2007 to November 2009 show that in general the wettest months are December and January with the driest being May and June (figure 3). This is largely in agreement with the in situ soil moisture measurements shown in figure 2.

Overall, no discernible association between precipitation and the multi-temporal backscatter signatures is evident from the data. On some acquisition dates, it appears that rainfall was associated with an increase in backscatter. However, on other dates, the amount of rainfall seemed to have little or no influence on the backscatter. Strong temporal variations in the observed backscatter across all sites are observed in figure 3 , with many abrupt increases (spikes) occurring throughout the year. This behaviour stabilised to some degree from about April 2009 to October 2009. November 2009 is notable for the high rainfall recorded across all study sites (except Carraig na bhFear due to a suspected instrument fault) and the considerable increase in the backscatter during this period (figure 3).

Figure 3.

\subsection{Regression Analysis}

A regression analysis was performed for each polarisation separately. In the VV polarisation dataset, the backscatter and soil moisture relationship was initially investigated for each study site using the two-year dataset as a whole, and was subsequently divided into investigating the inter-annual and inter-seasonal relationships. Due to the low number of acquisitions, a comparable analysis could not be performed for the $\mathrm{HH}$ dataset (acquisition dates ranging from $27^{\text {th }}$ June $2008-4^{\text {th }}$ December 2009). Linear regression functions of the form $\sigma^{0}=\mathrm{B}_{0}+\mathrm{B}_{1} \cdot m_{v}$ were computed, where $\sigma^{0}$ is the mean backscatter coefficient $(\mathrm{dB}), \mathrm{B}_{0}$ is the intercept, $\mathrm{B}_{1}$ is the slope of the regression equation and $m_{v}$ is the volumetric soil moisture (\%). The slope is used as an indicator of the sensitivity of $\sigma^{0}$ to $m_{v}$. The significance of the linear relationship 
between the soil moisture measurements and the backscattering coefficient was tested using Fisher's $F$ test for $\alpha=0.05$ significance level. The P-value (two-tailed) calculated from the $F$ test is shown for each analysis (in table 2 and in each plot of figure 4, figure 5 and figure 6 ).

The relationship between the $\sigma^{0}$ measured in $\mathrm{HH}$ polarisation and volumetric soil moisture for each study site was calculated and is displayed in figure 4 . The regression equation for each site is shown along with the $95 \%$ confidence limits of the regression line, denoted by dashed lines. The radar backscatter clearly increases with increasing soil moisture at the majority of sites. Significant positive correlations $(p<0.05)$ were observed for five out of the seven study sites, with Donoughmore and Ballinhassig displaying non-significant positive correlations. The slope of the relationship varies from one site to another, ranging from 0.06 (Donoughmore) to 0.13 (Kilworth).

Figure 4.

The relationship between the $\sigma^{0}$ measured in VV polarisation and volumetric soil moisture for each study site is displayed in table 2. Generally weak to moderate significant positive relationships are observed for each site. To understand the interannual and seasonal variability of soil moisture during the study period the yearly and seasonal soil moisture and backscatter relationships were calculated. The inter-annual variations in VV polarisation backscatter as a function of volumetric soil moisture for each test site are plotted in figure 5 for 2008 and figure 6 for 2009. Across all sites, the backscatter coefficient for 2008 varied from approximately -12 to $-4 \mathrm{~dB}$ for a variation in soil moisture from about 17 to $70 \%$. In 2009 , the $\sigma^{0}$ variation is approximately -12 to $-6 \mathrm{~dB}$ for soil moisture ranging from 17 to $82 \%$. The regression equations for 2008 (figure 5) show low correlations and dispersions are high for all study sites. The highest significant correlations were observed for the Donoughmore $\left(\mathrm{r}^{2}=0.47, \mathrm{p}<0.001\right)$ and Solohead $\left(\mathrm{r}^{2}=0.31, \mathrm{p}=0.002\right)$ sites. The 2009 coefficients of determination are generally stronger, ranging from 0.26 to 0.68 . The highest significant correlations were observed for the Clonakilty $\left(\mathrm{r}^{2}=0.68, \mathrm{p}<0.001\right)$ and Kilworth $\left(\mathrm{r}^{2}=0.53, \mathrm{p}<0.001\right)$ sites. The Donoughmore $\left(r^{2}=0.39, p=0.001\right)$ and Solohead $\left(r^{2}=0.45, p<0.001\right)$ sites displayed similar relationships to their respective 2008 datasets. The individual slopes (i.e. radar sensitivity to soil moisture) corresponding to the two sites are approximately the same for both years.

Table 2.

Figure 5.

Figure 6. 
The coefficients of determination observed in this study were lower than those found in previous investigations using ERS-1/2 (Image mode, VV polarisation) SAR data (e.g. Cognard et al. (1995), Weimann et al. (1998), Moeremans and Dautrebande (2000), Quesney et al. (2000), Shoshany et al. (2000), Le Hegarat-Mascle et al. (2002), Haider et al. (2004)). Furthermore, the slopes of the regression equations derived in this study were much lower, though the intercept values are within the variation of those reported in previous studies ( -10 to -14). For example, Le Hegarat-Mascle et al. (2002) found a slope of 0.33-0.34 and Weimann et al. (1998) a slope of 0.55. However, Kong and Dorling (2008) found a similar coefficient of determination $\left(\mathrm{r}^{2}=0.46\right)$ and slope $\left(\mathrm{B}_{1}=0.12\right)$ for a grasslands site in the UK, as did Van der Velde et al. (2008) who derived a coefficient of determination of $r^{2}=0.43$ and slope $B_{1}=0.16$ for a grasslands site in Tibet, both using ASAR WSM VV datasets. The correlations and slopes of the regression lines using $\mathrm{HH}$ polarisation (figure 4) were generally higher than those observed for the VV polarisation dataset (figure 5 and 6). Although the $\mathrm{HH}$ polarisation dataset contains considerably fewer samples, this observation is consistent with Le Morvan et al. (2008) who found the sensitivity of soil moisture to radar backscatter at $\mathrm{HH}$ polarisation to be marginally higher than that from VV polarisation.

The seasonal variations in backscatter as a function of soil moisture at each of the test sites for 2008 and 2009 were also investigated. The seasons are classed as per the meteorological season for the Northern hemisphere, i.e. winter begins on the $1^{\text {st }}$ December, spring on $1^{\text {st }}$ March, summer on $1^{\text {st }}$ June, and autumn on $1^{\text {st }}$ September. Statistics related to the seasonal regression functions are given in table 3 . The coefficients describing the relationships are different from one site to another and also from one year to the next. A large number of the regressions display poor correlations between the soil moisture and radar signal. Six seasonal datasets for 2008 display significant positive correlations $\left(\mathrm{r}^{2}\right.$ ranging from 0.38 to 0.60$)$ while thirteen datasets in 2009 display significant positive correlations $\left(\mathrm{r}^{2}\right.$ ranging from 0.39 to 0.99$)$. The sensitivity of $\sigma^{0}$ to $m_{v}$ also varies for each of these datasets, ranging from 0.05 to $0.13 \mathrm{~dB} / \%$ for 2008 and 0.04 to $0.17 \mathrm{~dB} / \%$ for 2009 .

Given the large fluctuations in soil moisture throughout the year, it was hypothesised that a seasonal analysis could provide improved results, as opposed to analysing the observations for the year as a whole. For example, Hupet and Vanclooster (2002) found surface soil moisture variability to increase strongly during the vegetative growth period (due to evapotranspiration and water uptake by plants). Similarly, Illston et al. (2004) found lower soil moisture variability during the winter and spring than during summer and autumn for a dataset of 58 sites over a six year time-period in Oklahoma. Consequently, the winter (wetter) datasets would be considered to theoretically provide the best results. This was not observed to be the case in this study, as only one winter dataset displayed a significant positive correlation - Clonakilty in 2009. An analysis of temperature recordings for up to five hours before each winter-time image acquisition revealed no instances of the soil temperature dropping below $0^{\circ} \mathrm{C}$ (frozen soils) which might have provided a possible explanation for the observed low correlations.

Table 3. 
The spring datasets comprised the majority of significant correlations (four in 2008 and four in 2009). The Solohead, Kilworth and Ballinhassig sites all displayed significant correlations during both 2008 and 2009. The autumn datasets displayed the highest coefficients of determination, with an $\mathrm{r}^{2}$ of 0.60 in 2008 (Donoughmore) and $\mathrm{r}^{2}$ ranging from 0.78 to 0.99 in 2009. The slopes of the autumn 2009 relationships are relatively consistent for the Pallaskenry, Kilworth and Clonakilty sites (ranging from $0.12-0.16$ ) and for the Solohead, Carraig na bhFear and Ballinhassig sites (ranging from $0.04-$ $0.08)$.

The spatial variability of the soil moisture is likely to be due to differences in radiation effects, gains due to precipitation, losses due to evapotranspiration, runoff and drainage, and heterogeneities in soil and vegetation characteristics (Brocca et al. 2007). The observed variation in backscatter as a function of soil moisture was likely to have been caused by several factors. In terms of image calibration, the influence of speckle can cause pixel values to vary randomly. In this study, the influence of speckle was considered to be low as an appropriate preprocessing was carried out with a suitable number of looks. Similarly, the low coefficients of determination observed between the backscatter and soil moisture time-series does not necessarily point to an alternative and dominating influence (e.g. surface roughness or vegetation), but might be due to the scaling problem (Pathe et al. 2009). The spatial scale at which the backscatter and soil moisture relationship is determined is of critical importance (Zribi et al. 2005). At larger scales, the sub-pixel heterogeneity (in terms of vegetation, surface roughness and moisture) can invariably lead to errors in the estimated soil moisture values. In this study, discrete soil moisture measurements were compared to backscatter values corresponding to an area of $375 \mathrm{~m}$ x $375 \mathrm{~m}$. The increased scale increases soil moisture variability as the spatial heterogeneities in factors such as topography, vegetation and surface roughness also become larger.

\section{Conclusions}

The aim of this study was to assess the relationship between ASAR WSM backscatter and variations in surface soil moisture at several test sites located in the south of Ireland over a two year period. Empirical regressions were formulated using ASAR WSM data (acquired in $\mathrm{HH}$ and VV polarisation) and in situ measurements of soil moisture. The need for measurements of other surface parameters such as surface roughness and vegetation is removed using this approach. For dominantly vertical-oriented vegetation cover (e.g. grasslands), the use of HH polarisation is considered best for soil moisture estimation. The default mode for ASAR WSM acquisitions is VV polarisation so it was not possible to acquire a larger HH polarisation dataset for this study. Nonetheless, the $\mathrm{HH}$ polarisation images (seven in total) acquired during summer and winter months displayed strong significant correlations between $\sigma^{0}$ and $m_{v}$ for five out of the seven test sites. Similarly, several of the test sites displayed significant correlations in VV polarisation for images acquired throughout 2008 and 2009 respectively. The seasonal analysis of the VV polarisation data showed that the radar signal is more sensitive to surface soil moisture during the spring and autumn months, with average backscatter increases of about $1 \mathrm{~dB}$ per $10 \%$ increase in soil moisture. 
It must be noted that the derived regression equations are only valid for the given sensor wavelength (C-band) and are site-specific (low lying grassland) where a negligible influence of vegetation and surface roughness was assumed. While many studies have operated on the premise of negligible surface roughness change and vegetation contributions, further research in this area is required to understand the biases and temporal error introduced by neglecting these effects. The high seasonal and interannual variability observed in this dataset highlights the importance of formulating algorithms that are successful from one year to the next. In order to determine a true model of the backscatter-soil moisture relationship for a particular area, and for a robust validation of the assumptions of the empirical approach, it would be necessary to have uniform, continuous and prolonged observations at a larger number of well-distributed monitoring stations. For example, the temporal stability concept, introduced by Vachaud et al. (1985) reduces the need for a large ground-based soil moisture measurement network by identifying a few single (well-distributed) in situ stations whose soil moisture measurements are representative of the mean soil moisture over an area (i.e. display similar absolute values and temporal trends) where various studies (e.g. Cosh et al. 2006, Wagner et al. 2008) have demonstrated that time invariant relationships can be used to predict soil moisture from backscatter measurements across different spatial scales.

Although some of the reported correlations were low, there was still an evident positive relationship between the observed soil moisture values and the normalised radar backscatter. Considering the uncertainties involved, the reported regressions are encouraging and demonstrate the potential of simple empirical models for retrieving surface soil moisture from WSM data.

\section{Acknowledgements}

The authors would like to thank the European Space Agency (ESA) for providing the SAR data under Category-1 project ID 5012. The authors would also like to acknowledge the Irish Environmental Protection Agency (EPA) for supporting this research through the Science, Technology, Research and Innovation for the Environment (STRIVE) Programme, financed by the Irish Government under the National Development Plan (NDP) 2007-2013. The assistance of Dr. Paul Leahy from the Department of Civil Engineering, University College Cork (UCC), for providing access to the AEON site measurements is also greatly appreciated. 


\section{References}

ALTESE, E., BOLOGNANI, O., MANCINI, M., and TROCH, P. A., 1996, Retrieving soil moisture over bare soil from ERS 1 synthetic aperture radar data: Sensitivity analysis based on a theoretical surface scattering model and field data. Water Resources Research, 32, pp. 653-661.

BAGHDADI, N., CERDAN, O., ZRIBI, M., AUZET, V., DARBOUX, F., HAJJ, M. E., and KHEIR, R. B., 2008, Operational performance of current synthetic aperture radar sensors in mapping soil surface characteristics in agricultural environments: application to hydrological and erosion modelling. Hydrological Processes, 22, pp. 9-20.

BAGHDADI, N., HOLAH, N., and ZRIBI, M., 2006, Soil moisture estimation using multiincidence and multipolarization ASAR data. International Journal of Remote Sensing, 27, pp. 1907-1920.

BARRETT, B., DWYER, E., and WHELAN, P., 2009, Soil moisture retrieval from active spaceborne microwave observations: An evaluation of current techniques. Remote Sensing, 1, pp. 210-242.

BAUP, F., MOUGIN, E., DE ROSNAY, P., TIMOUK, F., and CHÊNERIE, I., 2007, Surface soil moisture estimation over the AMMA Sahelian site in Mali using ENVISAT/ASAR data. Remote Sensing of Environment, 109, pp. 473-481.

BROCCA, L., MELONE, F., MORAMARCO, T., and MORBIDELLI, R., 2010, Spatial-temporal variability of soil moisture and its estimation across scales. Water Resources Research, 46, pp. W02516.

BROCCA, L., MORBIDELLI, R., MELONE, F., and MORAMARCO, T., 2007, Soil moisture spatial variability in experimental areas of central Italy. Journal of Hydrology, 333, pp. 356-373.

CAMPBELL SCIENTIFIC, 2004, Instruction Manual: CS616 and CS625 Water Content Reflectometers,

(Logan, Utah: Campbell Scientific), Available at: http://www.campbellsci.com/documents/manuals/cs616.pdf (last accessed 7th December 2010).

COGNARD, A., LOUMAGNE, C., NORMAND, M., OLIVIER, P., OTTLÉ, C., VIDAL-MADJAR, D., LOUAHALA, S., and VIDAL, A., 1995, Evaluation of the ERS 1/synthetic aperture radar capacity to estimate surface soil moisture: Two-year results over the Naizin watershed. Water Resources Research, 31, pp. 975-982.

COSH, M. H., JACKSON, T. J., STARKS, P., and HEATHMAN, G., 2006, Temporal stability of surface soil moisture in the Little Washita River watershed and its applications in satellite soil moisture product validation. Journal of Hydrology, 323, pp. 168-177.

DALY, E., and PORPORATO, A., 2005, A review of soil moisture dynamics: from rainfall infiltration to ecosystem response. Environmental engineering science, 22, pp. 9-24.

DESNOS, Y., BUCK, C., GUIJARRO, J., SUCHAIL, J., TORRES, R., and ATTEMA, E., 2000, ASAREnvisat's Advanced Synthetic Aperture Radar. ESA BULLETIN, 102, pp. 91-100.

DOBSON, M., PIERCE, L., SARABANDI, K., ULABY, F., and SHARIK, T., 1992, Preliminary analysis of ERS-1 SAR for forest ecosystem studies. IEEE Transactions on Geoscience and Remote Sensing, 30, pp. 203-211.

DUBOIS, P. C., VAN ZYL, J., and ENGMAN, T., 1995, Measuring soil moisture with imaging radars. IEEE Transactions on Geoscience and Remote Sensing, 33, pp. 915-926.

ENTEKHABI, D., RODRIGUEZ-ITURBE, I., and CASTELLI, F., 1996, Mutual interaction of soil moisture state and atmospheric processes. Journal of Hydrology, 184, pp. 3-17.

FAMIGLIETTI, J., DEVEREAUX, J., LAYMON, C., TSEGAYE, T., HOUSER, P., JACKSON, T., GRAHAM, S., RODELL, M., and VAN OEVELEN, P., 1999, Ground-based investigation of soil moisture variability within remote sensing footprints during the Southern Great Plains 1997 (SGP 97) Hydrology Experiment. Water Resources Research, 35, pp. 1839-1851.

FUNG, A. K., LI, Z., and CHEN, K. S., 1992, Backscattering from a randomly rough dielectric surface. IEEE Transactions on Geoscience and Remote Sensing, 30, pp. 356-369.

HAIDER, S., SAID, S., KOTHYARI, U., and ARORA, M., 2004, Soil moisture estimation using ERS 2 SAR data: a case study in the Solani River catchment/Estimation de l'humidité du sol grâce à des données ERS-2 SAR: étude de cas dans le bassin de la rivière Solani. Hydrological Sciences Journal, 49, pp. 323334.

HAWLEY, M., JACKSON, T., and MCCUEN, R., 1983, Surface soil moisture variation on small agricultural watersheds. Journal of Hydrology, 62, pp. 179-200.

HUPET, F., and VANCLOOSTER, M., 2002, Intraseasonal dynamics of soil moisture variability within a small agricultural maize cropped field. Journal of Hydrology, 261, pp. 86-101. 
ILLSTON, B., BASARA, J., and CRAWFORD, K., 2004, Seasonal to interannual variations of soil moisture measured in Oklahoma. International Journal of Climatology, 24, pp. 1883-1896.

KONG, X., and DORLING, S. R., 2008, Near-surface soil moisture retrieval from ASAR Wide Swath imagery using a Principal Component Analysis. International Journal of Remote Sensing, 29, pp. 29252942.

LE HEGARAT-MASCLE, S., ZRIBI, M., ALEM, F., WEISSE, A., and LOUMAGNE, C., 2002, Soil moisture estimation from ERS/SAR data: toward an operational methodology. IEEE Transactions on Geoscience and Remote Sensing, 40, pp. 2647-2658.

LE MORVAN, A., ZRIBI, M., BAGHDADI, N., and CHANZY, A., 2008, Soil moisture profile effect on radar signal measurement. Sensors, 8, pp. 256-270.

LOEW, A., LUDWIG, R., and MAUSER, W., 2006, Derivation of surface soil moisture from ENVISAT ASAR wide swath and image mode data in agricultural areas. IEEE Transactions on Geoscience and Remote Sensing, 44, pp. 889-899.

MOEREMANS, B., and DAUTREBANDE, S., 2000, Soil moisture evaluation by means of multitemporal ERS SAR PRI images and interferometric coherence. Journal of Hydrology, 234, pp. 162-169.

OH, Y., SARABANDI, K., and ULABY, F. T., 2002, Semi-empirical model of the ensemble-averaged differential Mueller matrix for microwave backscattering from bare soil surfaces. IEEE Transactions on Geoscience and Remote Sensing, 40, pp. 1348-1355.

PATHE, C., WAGNER, W., SABEL, D., DOUBKOVA, M., and BASARA, J. B., 2009, Using ENVISAT ASAR Global Mode Data for Surface Soil Moisture Retrieval over Oklahoma, USA. IEEE Transactions on Geoscience and Remote Sensing, 47, pp. 468-480.

QUESNEY, A., LE HÉGARAT-MASCLE, S., TACONET, O., VIDAL-MADJAR, D., WIGNERON, J., LOUMAGNE, C., and NORMAND, M., 2000, Estimation of watershed soil moisture index from ERS/SAR data. Remote Sensing of Environment, 72, pp. 290-303.

SCHULTE, R., DIAMOND, J., FINKELE, K., HOLDEN, N., and BRERETON, A., 2005, Predicting the soil moisture conditions of Irish grasslands. Irish Journal of Agricultural and Food Research, 44, pp. 95110.

SHOSHANY, M., SVORAY, T., CURRAN, P. J., FOODY, G. M., and PEREVOLOTSKY, A., 2000, The relationship between ERS-2 SAR backscatter and soil moisture: generalization from a humid to semiarid transect. International Journal of Remote Sensing, 21, pp. 2337-2343.

SONG, K., ZHOU, X., and FAN, Y., 2009, Empirically adopted IEM for retrieval of soil moisture from radar backscattering coefficients. IEEE Transactions on Geoscience and Remote Sensing, 47, pp. 16621672.

SRIVASTAVA, H. S., PATEL, P., MANCHANDA, M. L., and ADIGA, S., 2003, Use of multiincidence angle RADARSAT-1 SAR data to incorporate the effect of surface roughness in soil moisture estimation. IEEE Transactions on Geoscience and Remote Sensing, 41, pp. 1638-1640.

TEAGASC, 2010, Agriculture in Ireland. Available at: http://www.teagasc.ie/agrifood/ (last accessed $8^{\text {th }}$ February 2011).

TEULING, A., and TROCH, P., 2005, Improved understanding of soil moisture variability dynamics. Geophysical Research Letters, 32, pp. L05404.

TROMP-VAN MEERVELD, H., and MCDONNELL, J., 2006, On the interrelations between topography, soil depth, soil moisture, transpiration rates and species distribution at the hillslope scale. Advances in Water Resources, 29, pp. 293-310.

ULABY, F., MOORE, R., and FUNG, A., 1982, Microwave Remote Sensing: Active and Passive Radar Remote Sensing and Surface Scattering and Emission Theory, Volume II (Reading, Massachusetts: Addison-Wesley).

ULABY, F. T., MOORE, R. K., and FUNG, A. K., 1986, Microwave Remote Sensing: Active and Passive. Volume Scattering and Emission Theory, Advanced Systems and Applications, Volume III (Dedham, Massachusetts: Artech House).

ULABY F. T. and DOBSON, C., 1989, Handbook of Radar Scattering Statistics for Terrain. Artech House.

VACHAUD, G., BALABANIS, A., and VAUCLIN, P., 1985, Temporal Stability of Spatially Measured Soil Water Probability Density Function. Soil Science Society of America Journal, 49, pp. 822.

VAN DER VELDE, R., SU, Z., and MA, Y., 2008, Impact of Soil Moisture Dynamics on ASAR s o Signatures and Its Spatial Variability Observed over the Tibetan Plateau. Sensors, 8, pp. 5479-5491.

VAN DONINCK, J., PETERS, J., LIEVENS, H., DE BAETS, B. \& VERHOEST, N. 2012. Accounting for seasonality in a soil moisture change detection algorithm for ASAR Wide Swath time series.

Hydrology and Earth System Sciences, 16, pp. 773-786. 
WAGNER, W., and SCIPAL, K., 2000, Large-scale soil moisture mapping in western Africa using the ERS scatterometer. IEEE Transactions on Geoscience and Remote Sensing, 38, pp. 1777-1782.

WAGNER, W., PATHE, C., DOUBKOVA, M., SABEL, D., BARTSCH, A., HASENAUER, S., BLÖSCHL, G., SCIPAL, K., MARTÍNEZ-FERNÁNDEZ, J., and LÖW, A., 2008, Temporal Stability of Soil Moisture and Radar Backscatter Observed by the Advanced Synthetic Aperture Radar (ASAR).

Sensors, 8, pp. 1174-1197.

WALKER, J. P., and HOUSER, P. R., 2004, Requirements of a global near-surface soil moisture satellite mission: accuracy, repeat time, and spatial resolution. Advances in Water Resources, 27, pp. 785-801.

WEIMANN, A., VON SCHONERMARK, M., SCHUMANN, A., JORN, P., and GUNTHER, R., 1998, Soil moisture estimation with ERS-1 SAR data in the East-German loess soil area. International Journal of Remote Sensing, 19, pp. 237-243.

WICKEL, A., JACKSON, T., and WOOD, E., 2001, Multitemporal monitoring of soil moisture with RADARSAT SAR during the 1997 Southern Great Plains hydrology experiment. International Journal of Remote Sensing, 22, pp. 1571-1583.

ZRIBI, M., BAGHDADI, N., HOLAH, N., and FAFIN, O., 2005, New methodology for soil surface moisture estimation and its application to ENVISAT-ASAR multi-incidence data inversion. Remote Sensing of Environment, 96, pp. 485-496.

ZRIBI, M., and DECHAMBRE, M., 2002, A New Empirical Model to Retrieve Soil Moisture and Roughness from C-band Radar Data. Remote Sensing of Environment, 84, pp. 42-52. 


\section{Appendix 1.}

A.1: ASAR WSM acquisition characteristics. Study sites: $\mathrm{P}=$ Pallaskenry, $\mathrm{S}=$ Solohead, $\mathrm{K}=$ Kilworth, $\mathrm{D}=$ Donoughmore, $\mathrm{C}=$ Clonakilty, $\mathrm{B}=$ Ballinhassig. 'All' indicates that every site was covered by the image swath coverage.

\begin{tabular}{|c|c|c|c|c|c|c|c|}
\hline$\#$ & Date & Time & Polarisation & Orbit & Track & Frame & Study Site \\
\hline 1 & $11^{\text {th }}$ Nov2007 & $10: 42: 24$ & VV & 29793 & 180 & 2591 & Not P \\
\hline 2 & $20^{\text {th }}$ Nov2007 & $10: 59: 21$ & VV & 29922 & 309 & 2560 & All \\
\hline 3 & $7^{\text {th }}$ Jan2008 & $10: 50: 47$ & VV & 30609 & 495 & 2574 & All \\
\hline 4 & $20^{\text {th }} \mathrm{Jan} 2008$ & $10: 42: 22$ & VV & 30795 & 180 & 2590 & Not P \\
\hline 5 & $26^{\text {th }}$ Jan2008 & $10: 53: 39$ & VV & 30881 & 266 & 2563 & All \\
\hline 6 & $29^{\text {th }} \mathrm{Jan} 2008$ & 10:59:21 & VV & 30924 & 309 & 2560 & All \\
\hline 7 & $1^{\text {st }} \mathrm{Feb} 2008$ & $11: 04: 27$ & VV & 30967 & 352 & 2550 & Not K \\
\hline 8 & $8^{\text {th }}$ Feb2008 & $10: 45: 05$ & VV & 31067 & 452 & 2569 & All \\
\hline 9 & $17^{\text {th }}$ Mar2008 & $10: 50: 49$ & VV & 31611 & 495 & 2566 & All \\
\hline 10 & $18^{\text {th }}$ Apr2008 & $10: 45: 11$ & VV & 32069 & 452 & 2589 & All \\
\hline 11 & $21^{\text {st }}$ Apr2008 & $10: 50: 47$ & VV & 32112 & 495 & 2565 & All \\
\hline 12 & $4^{\text {th }}$ May2008 & $10: 42: 15$ & VV & 32298 & 180 & 2570 & Not P \\
\hline 13 & $7^{\text {th }}$ May2008 & $10: 47: 57$ & VV & 32341 & 223 & 2567 & All \\
\hline 14 & $10^{\text {th }}$ May 2008 & 10:53:39 & VV & 32384 & 266 & 2563 & All \\
\hline 15 & $23^{\text {rd }}$ May2008 & $10: 45: 06$ & VV & 32570 & 452 & 2569 & All \\
\hline 16 & $26^{\text {th }}$ May 2008 & $10: 50: 48$ & VV & 32613 & 495 & 2565 & All \\
\hline 17 & $11^{\text {th }}$ Jun2008 & $10: 47: 58$ & VV & 32842 & 223 & 2567 & All \\
\hline 18 & $27^{\text {th }}$ Jun2008 & $22: 07: 14$ & $\mathrm{HH}$ & 33078 & 459 & 1000 & All \\
\hline 19 & $30^{\text {th }}$ Jun2008 & $10: 50: 49$ & VV & 33114 & 495 & 2565 & All \\
\hline 20 & $13^{\text {th }}$ Jul2008 & $10: 42: 17$ & VV & 33300 & 180 & 2570 & Not P \\
\hline 21 & $16^{\text {th }} \mathrm{Jul} 2008$ & $10: 47: 59$ & VV & 33343 & 223 & 2567 & All \\
\hline 22 & $7^{\text {th }}$ Aug2008 & $10: 56: 32$ & VV & 33658 & 37 & 2562 & All \\
\hline 23 & $21^{\text {st }}$ Sep2008 & 22:04:59 & VV & 34309 & 187 & 1036 & All \\
\hline 24 & $24^{\text {th }}$ Sep2008 & $10: 48: 10$ & VV & 34345 & 223 & 2580 & All \\
\hline $\begin{array}{l}25 \\
26\end{array}$ & $\begin{array}{l}10^{\text {th }} \text { Oct } 2008 \\
13^{\text {th }} \text { Oct } 2008\end{array}$ & $\begin{array}{l}10: 44: 56 \\
10: 50: 38\end{array}$ & $\begin{array}{l}\text { VV } \\
\text { VV }\end{array}$ & $\begin{array}{l}34574 \\
34617\end{array}$ & $\begin{array}{l}452 \\
495\end{array}$ & $\begin{array}{l}2569 \\
2565\end{array}$ & $\begin{array}{l}\text { All } \\
\text { All }\end{array}$ \\
\hline 27 & $11^{\text {th }}$ Nov 2008 & $22: 01: 57$ & VV & 35039 & 416 & 1038 & $\begin{array}{l}\text { Not P, C, } \\
\text { B. D }\end{array}$ \\
\hline 28 & $17^{\text {th }}$ Nov 2008 & $10: 50: 38$ & VV & 35118 & 495 & 2569 & All \\
\hline 29 & $3^{\text {rd }}$ Dec 2008 & $10: 48: 21$ & VV & 35347 & 223 & 2590 & Not $\mathrm{P}$ \\
\hline 30 & $6^{\text {th }}$ Dec 2008 & $10: 52: 26$ & VV & 35390 & 266 & 2563 & All \\
\hline 31 & $12^{\text {th }}$ Dec 2008 & 11:03:39 & VV & 35476 & 352 & 2551 & Not K \\
\hline 32 & $28^{\text {th }}$ Dec 2008 & 11:01:08 & VV & 35705 & 080 & 2558 & All \\
\hline 33 & $7^{\text {th }}$ Jan 2009 & $10: 47: 06$ & VV & 35848 & 223 & 2567 & All \\
\hline 34 & $10^{\text {th }}$ Jan 2009 & $10: 53: 34$ & VV & 35891 & 266 & 2572 & All \\
\hline 35 & $10^{\text {th }}$ Jan 2009 & $22: 16: 11$ & $\mathrm{HH}$ & 35898 & 273 & 1028 & All \\
\hline 36 & $13^{\text {th }}$ Jan 2009 & 11:00:10 & $\mathrm{HH}$ & 35934 & 309 & 2560 & All \\
\hline 37 & $13^{\text {th }}$ Jan 2009 & $22: 22: 54$ & $\mathrm{HH}$ & 35941 & 316 & 1025 & Not C, B \\
\hline 38 & $16^{\text {th }}$ Jan 2009 & 11:05:51 & VV & 35977 & 352 & 2556 & Not K \\
\hline 39 & $1^{\text {st }}$ Feb 2009 & $11: 02: 59$ & VV & 36206 & 80 & 2558 & All \\
\hline 40 & $8^{\text {th }}$ Feb 2009 & $10: 43: 05$ & VV & 36305 & 180 & 2570 & Not P \\
\hline
\end{tabular}




\begin{tabular}{|c|c|c|c|c|c|c|c|}
\hline 41 & $11^{\text {th }}$ Feb 2009 & 10:49:06 & VV & 36349 & 223 & 2589 & All \\
\hline 42 & $14^{\text {th }}$ Feb 2009 & $10: 54: 29$ & VV & 35392 & 266 & 2563 & All \\
\hline 43 & $17^{\text {th }}$ Feb 2009 & 11:00:11 & VV & 36435 & 309 & 2560 & All \\
\hline 44 & $5^{\text {th }}$ Mar 2009 & $10: 56: 19$ & VV & 36664 & 37 & 2562 & All \\
\hline 45 & $8^{\text {th }}$ Mar 2009 & 11:02:01 & VV & 36707 & 80 & 2558 & All \\
\hline 46 & $18^{\text {th }}$ Mar 2009 & $10: 47: 46$ & VV & 36850 & 223 & 2567 & All \\
\hline 47 & $21^{\text {st }}$ Mar 2009 & $10: 53: 28$ & VV & 36893 & 266 & 2563 & All \\
\hline 48 & $27^{\text {th }}$ Mar 2009 & $11: 04: 52$ & VV & 36979 & 352 & 2556 & Not K \\
\hline 49 & $31^{\text {st }}$ Mar 2009 & $22: 02: 13$ & VV & 37043 & 416 & 1058 & Not C, B, \\
\hline 50 & $6^{\text {th }}$ April 2009 & $10: 50: 37$ & VV & 37122 & 495 & 2565 & All \\
\hline 51 & $12^{\text {th }}$ April 2009 & $11: 01: 58$ & VV & 37208 & 80 & 2558 & All \\
\hline 52 & $25^{\text {th }}$ April 2009 & $10: 54: 31$ & VV & 37394 & 266 & 2567 & All \\
\hline 53 & $5^{\text {th }}$ May 2009 & $22: 01: 57$ & VV & 37544 & 416 & 1038 & $\begin{array}{l}\text { Not C, B, } \\
\text { D. P }\end{array}$ \\
\hline 54 & $11^{\text {th }}$ May 2009 & $22: 13: 19$ & $\mathrm{VV}$ & 37630 & 1 & 1028 & All \\
\hline 55 & $12^{\text {th }}$ June 2009 & 22:07:40 & VV & 38088 & 459 & 1033 & All \\
\hline 56 & $18^{\text {th }}$ June 2009 & $10: 56: 20$ & VV & 38167 & 37 & 2562 & All \\
\hline 57 & $21^{\text {st }}$ June 2009 & 11:02:02 & VV & 38210 & 80 & 2558 & All \\
\hline 58 & $1^{\text {st }}$ July 2009 & $22: 10: 11$ & VV & 38360 & 230 & 1007 & Not P, S \\
\hline 59 & $4^{\text {th }}$ July 2009 & $22: 16: 14$ & VV & 38403 & 273 & 1029 & All \\
\hline 60 & $7^{\text {th }}$ July 2009 & 10:59:09 & $\mathrm{HH}$ & 38439 & 309 & 2559 & All \\
\hline 61 & $8^{\text {th }}$ Aug 2009 & $10: 54: 30$ & VV & 38897 & 266 & 2563 & All \\
\hline 62 & $15^{\text {th }}$ Sept 2009 & 10:59:13 & VV & 39441 & 309 & 2566 & All \\
\hline 63 & $1^{\text {st }}$ Oct 2009 & $10: 56: 14$ & VV & 39670 & 37 & 2561 & All \\
\hline 64 & $2^{\text {nd }}$ Nov 2009 & $10: 50: 33$ & VV & 40128 & 495 & 2565 & All \\
\hline 65 & $15^{\text {th }}$ Nov 2009 & $10: 42: 21$ & VV & 40314 & 180 & 2596 & Not P, S \\
\hline 66 & $18^{\text {th }}$ Nov 2009 & $10: 47: 41$ & VV & 40357 & 223 & 2566 & All \\
\hline 67 & $4^{\text {th }}$ Dec 2009 & $10: 44: 48$ & $\mathrm{HH}$ & 40586 & 452 & 2588 & All \\
\hline 68 & $4^{\text {th }} \operatorname{Dec} 2009$ & $22: 07: 33$ & $\mathrm{HH}$ & 40593 & 459 & 1036 & All \\
\hline
\end{tabular}




\section{Tables}

Table 1. Annual precipitation recorded at each study site.

\begin{tabular}{|c|c|c|c|}
\hline \multirow[t]{2}{*}{ Site } & \multirow[t]{2}{*}{ Coordinates } & \multicolumn{2}{|c|}{ Precipitation (mm) } \\
\hline & & 2008 & 2009 \\
\hline Pallaskenry & Lat. $52^{\circ} 39^{\prime} \mathrm{N}$, Long. $-8^{\circ} 51^{\prime} \mathrm{E}$ & 1147.9 & 1099.2 \\
\hline Solohead & Lat. $52^{\circ} 30^{\prime} \mathrm{N}$, Long. $-8^{\circ} 12^{\prime} \mathrm{E}$ & 1405.0 & 1403.2 \\
\hline Kilworth & Lat. $52^{\circ} 10^{\prime} \mathrm{N}$, Long. $-8^{\circ} 14^{\prime} \mathrm{E}$ & 772.3 & 1124.4 \\
\hline Donoughmore & Lat. $51^{\circ} 59^{\prime} \mathrm{N}$, Long. $-8^{\circ} 44^{\prime} \mathrm{E}$ & 1578.6 & 1763.4 \\
\hline Carraig na bhFear & Lat. $51^{\circ} 58^{\prime} \mathrm{N}$, Long. $-8^{\circ} 27^{\prime} \mathrm{E}$ & 824.4 & - \\
\hline Ballinhassig & Lat. $51^{\circ} 48^{\prime} \mathrm{N}$, Long. $-8^{\circ} 32^{\prime} \mathrm{E}$ & 1019.6 & 1343.3 \\
\hline Clonakilty & Lat. $51^{\circ} 37^{\prime} \mathrm{N}$, Long. $-8^{\circ} 50^{\prime} \mathrm{E}$ & 528.4 & 623.2 \\
\hline
\end{tabular}

Table 2. Backscatter and soil moisture regression statistics for the combined 2008 and 2009 VV polarisation dataset. $r^{2}$ is the coefficient of determination, $B_{1}$ is the slope of the regression equation and $\mathrm{n}$ is the number of samples used to calculate the regressions.

\begin{tabular}{lccccc}
\hline Site & $\mathrm{r}^{2}$ & Sig. & $\mathrm{n}$ & $\mathrm{B}_{\mathrm{o}}$ & $\mathrm{B}_{1}$ \\
\hline Pallaskenry & 0.19 & 0.002 & 50 & -11.542 & 0.04 \\
Solohead & 0.25 & $<0.001$ & 59 & -13.418 & 0.06 \\
Kilworth & 0.21 & $<0.001$ & 57 & -11.791 & 0.06 \\
Donoughmore & 0.40 & $<0.001$ & 57 & -13.982 & 0.11 \\
Carraig na bhFear & 0.14 & 0.006 & 54 & -11.563 & 0.04 \\
Ballinhassig & 0.33 & $<0.001$ & 58 & -11.214 & 0.04 \\
Clonakilty & 0.17 & $<0.001$ & 58 & -11.907 & 0.06 \\
\hline
\end{tabular}


Table 3. Inter-seasonal vv polarisation backscatter and soil moisture regression statistics. $\mathrm{r}^{2}$ is the coefficient of determination, $B_{1}$ is the slope of the regression equation and $n$ is the number of samples used to calculate the regressions.

\begin{tabular}{|c|c|c|c|c|c|c|c|}
\hline \multirow[t]{2}{*}{ Site } & \multirow[t]{2}{*}{ Season } & \multicolumn{2}{|c|}{$r^{2}$} & \multicolumn{2}{|c|}{$\mathrm{B}_{1}$} & \multicolumn{2}{|c|}{$\mathrm{N}$} \\
\hline & & 2008 & 2009 & 2008 & 2009 & 2008 & 2009 \\
\hline \multirow[t]{4}{*}{ Pallaskenry } & Winter & $0.45^{*}$ & 0.08 & -0.15 & 0.13 & 8 & 8 \\
\hline & Spring & 0.26 & 0.12 & 0.05 & 0.04 & 7 & 9 \\
\hline & Summer & 0.41 & 0.40 & 0.18 & -0.12 & 4 & 5 \\
\hline & Autumn & 0.006 & $0.99 * * *$ & -0.02 & 0.12 & 6 & 4 \\
\hline \multirow[t]{4}{*}{ Solohead } & Winter & 0.07 & 0.19 & 0.19 & -0.31 & 10 & 8 \\
\hline & Spring & $0.56^{* *}$ & $0.61 * * *$ & 0.09 & 0.15 & 8 & 11 \\
\hline & Summer & 0.003 & $0.74 *$ & -0.002 & 0.08 & 5 & 5 \\
\hline & Autumn & 0.006 & $0.81 *$ & -0.014 & 0.07 & 8 & 4 \\
\hline \multirow[t]{4}{*}{ Kilworth } & Winter & 0.04 & 0.07 & 0.13 & 0.84 & 8 & 7 \\
\hline & Spring & $0.47 *$ & $0.78 * * *$ & 0.10 & 0.16 & 8 & 10 \\
\hline & Summer & 0.002 & 0.04 & -0.006 & -0.02 & 5 & 6 \\
\hline & Autumn & 0.06 & $0.92 *$ & -0.06 & 0.15 & 8 & 5 \\
\hline \multirow[t]{4}{*}{ Donoughmore } & Winter & 0.05 & 0.34 & 0.08 & 0.24 & 10 & 8 \\
\hline & Spring & $0.44 *$ & 0.33 & 0.12 & 0.12 & 8 & 9 \\
\hline & Summer & 0.12 & 0.16 & 0.03 & 0.05 & 5 & 6 \\
\hline & Autumn & $0.60 * *$ & 0.42 & 0.13 & 0.09 & 7 & 4 \\
\hline \multirow[t]{4}{*}{ Carraig na bhFear } & Winter & 0.009 & 0.81 & -0.05 & 0.19 & 10 & 3 \\
\hline & Spring & 0.38 & 0.07 & 0.10 & 0.03 & 8 & 9 \\
\hline & Summer & 0.61 & 0.31 & 0.097 & 0.10 & 5 & 6 \\
\hline & Autumn & 0.04 & $0.78 * *$ & -0.03 & 0.08 & 8 & 5 \\
\hline \multirow[t]{4}{*}{ Ballinhassig } & Winter & 0.24 & 0.11 & 0.05 & -0.07 & 10 & 8 \\
\hline & Spring & $0.38^{*}$ & $0.39 *$ & 0.05 & 0.04 & 8 & 9 \\
\hline & Summer & 0.01 & $0.55^{*}$ & -0.01 & 0.06 & 5 & 6 \\
\hline & Autumn & 0.004 & $0.85^{* *}$ & 0.009 & 0.04 & 7 & 5 \\
\hline \multirow[t]{4}{*}{ Clonakilty } & Winter & 0.07 & $0.49 *$ & 0.14 & 0.17 & 10 & 8 \\
\hline & Spring & 0.05 & $0.50 * *$ & 0.045 & 0.08 & 8 & 9 \\
\hline & Summer & 0.50 & 0.28 & -0.20 & -0.02 & 5 & 6 \\
\hline & Autumn & 0.005 & $0.88^{* *}$ & 0.017 & 0.16 & 7 & 5 \\
\hline
\end{tabular}

* Significant at the 0.1 level

** Significant at the 0.05 level

*** Significant at the 0.01 level 


\section{List of Figures}

Figure 1. Field site locations in the south of Ireland (marked by yellow triangles) overlaid on ASAR WSM image subset. Red circles denote nearby Met Éireann climatological stations; from North, Shannon airport, Cork airport and Roches Point.

Figure 2. Temporal evolution of measured soil moisture (\%) at each of the seven study sites at time of SAR acquisition. Dashed lines represent the beginning of the seasons (i.e. winter begins on the $1^{\text {st }}$ December, spring on $1^{\text {st }}$ March, summer on $1^{\text {st }}$ June, and autumn on $1^{\text {st }}$ September).

Figure 3. Daily precipitation values (mm) (left y-axis) from 08/11/2007 to 30/12/2009 for each of the seven study sites along with the mean backscattering coefficient $(\mathrm{dB})$ for each image acquisition (blue line, right y-axis).

Figure 4. Sensitivity of the HH polarisation backscattering coefficients to surface soil moisture at each test site. Each point corresponds to the mean backscattering coefficient in $\mathrm{dB}$ for the different acquisition dates. The continuous line represents the regression line, calculated using the equation $\sigma^{0}=\mathrm{B}_{0}+\mathrm{B}_{1} m_{v}$, where $\mathrm{B}_{\mathrm{o}}$ is the intercept, $\mathrm{B}_{1}$ is the slope and $m_{v}$ is the volumetric soil moisture content. The dashed lines demarcate the $95 \%$ confidence intervals.

Figure 5. Sensitivity of the VV polarisation backscattering coefficients to surface soil moisture at each test site during 2008. Each point corresponds to the mean backscattering coefficient in $\mathrm{dB}$ for the different acquisition dates. The continuous line represents the regression equation $\sigma^{0}=\mathrm{B}_{\mathrm{o}}+\mathrm{B}_{1} m_{v}$, where $\sigma^{\mathrm{o}}$ is the backscattering coefficient, $\mathrm{B}_{\mathrm{o}}$ is the intercept, $\mathrm{B}_{1}$ is the slope and $m_{v}$ is the volumetric soil moisture content. The dashed lines represent the $95 \%$ confidence intervals.

Figure 6. Sensitivity of the VV polarisation backscattering coefficients to surface soil moisture at each test site during 2009. Each point corresponds to the mean backscattering coefficient in $\mathrm{dB}$ for the different acquisition dates. The continuous line represents the regression equation $\sigma^{0}=\mathrm{B}_{\mathrm{o}}+\mathrm{B}_{1} m_{v}$, where $\sigma^{\circ}$ is the backscattering coefficient, $\mathrm{B}_{\mathrm{o}}$ is the intercept, $\mathrm{B}_{1}$ is the slope and $m_{v}$ is the volumetric soil moisture content. The dashed lines represent the $95 \%$ confidence intervals. 
Figure 1

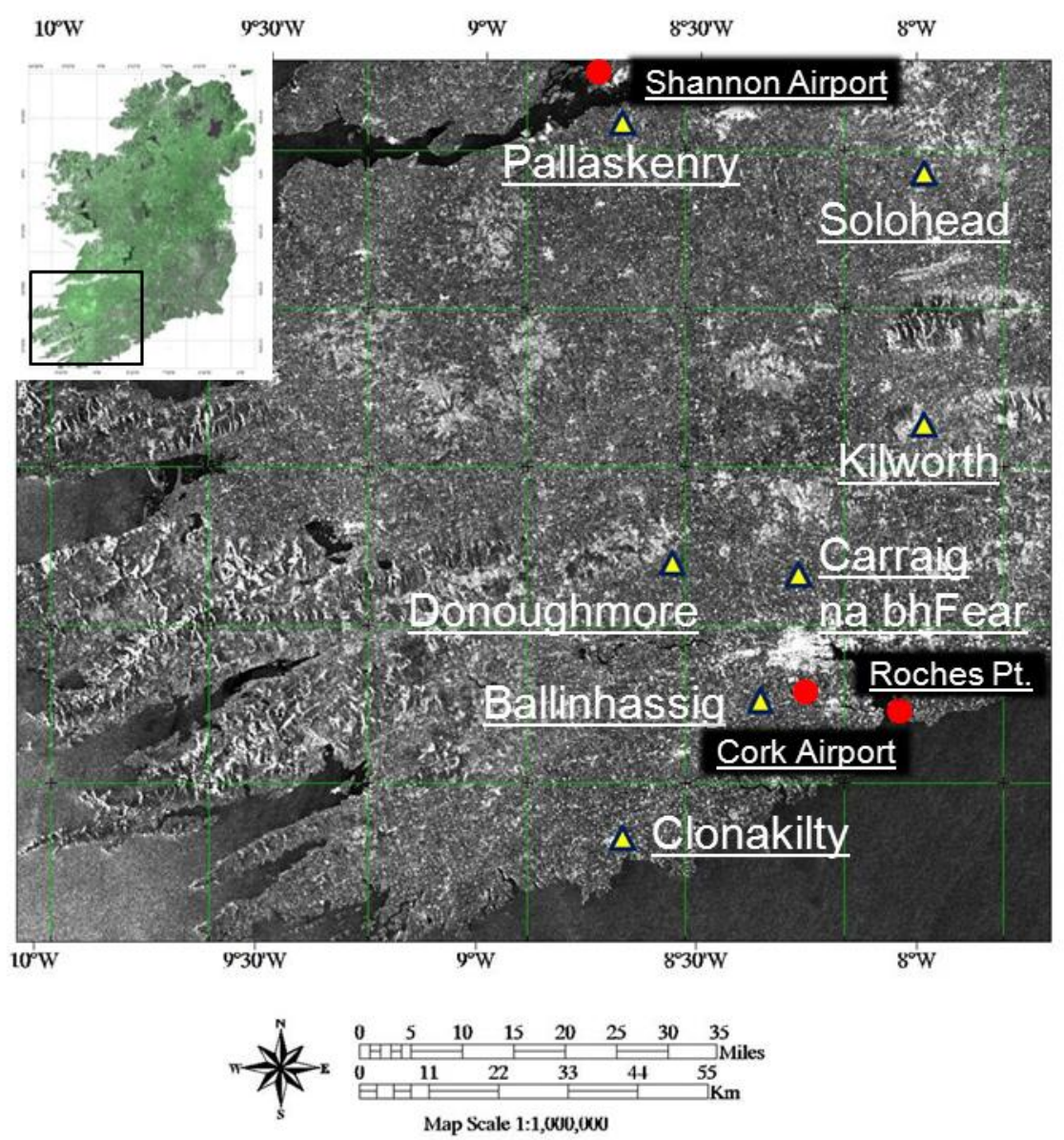


Figure 2

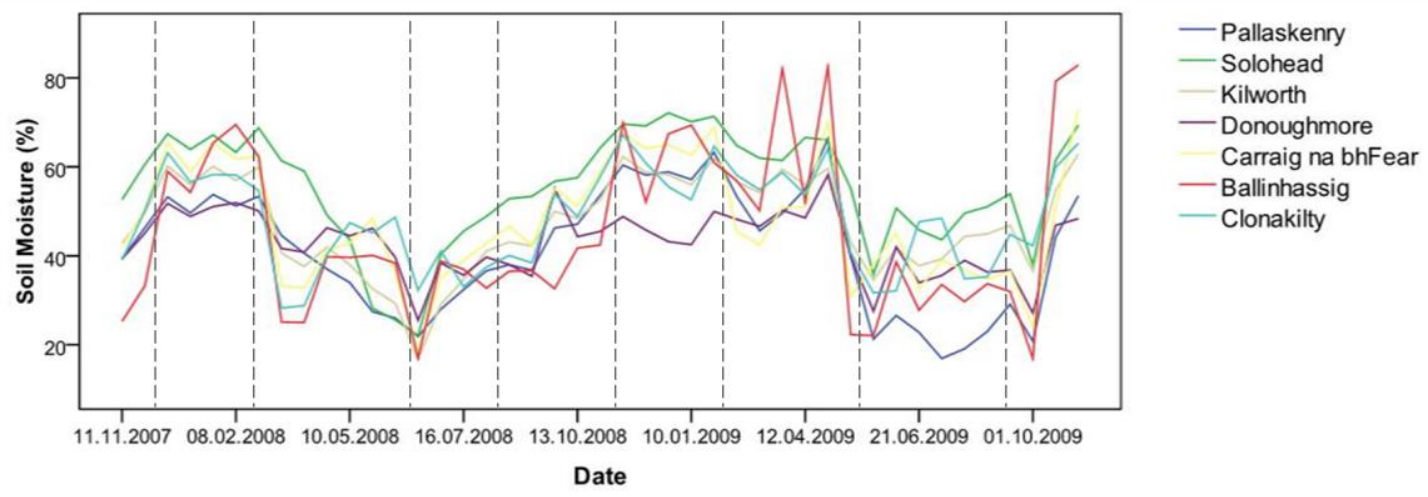


Figure 3
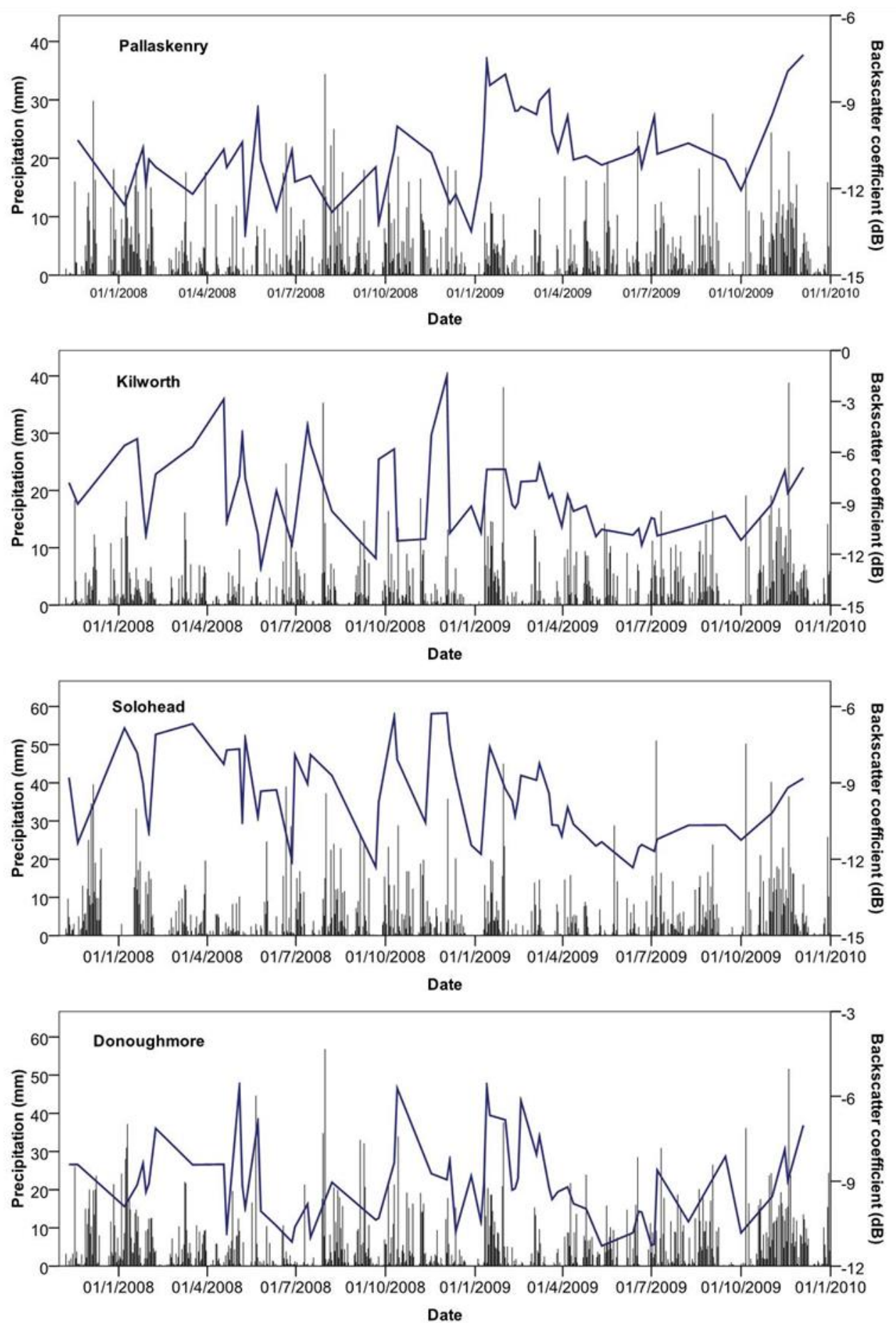
Figure 3 (cont)
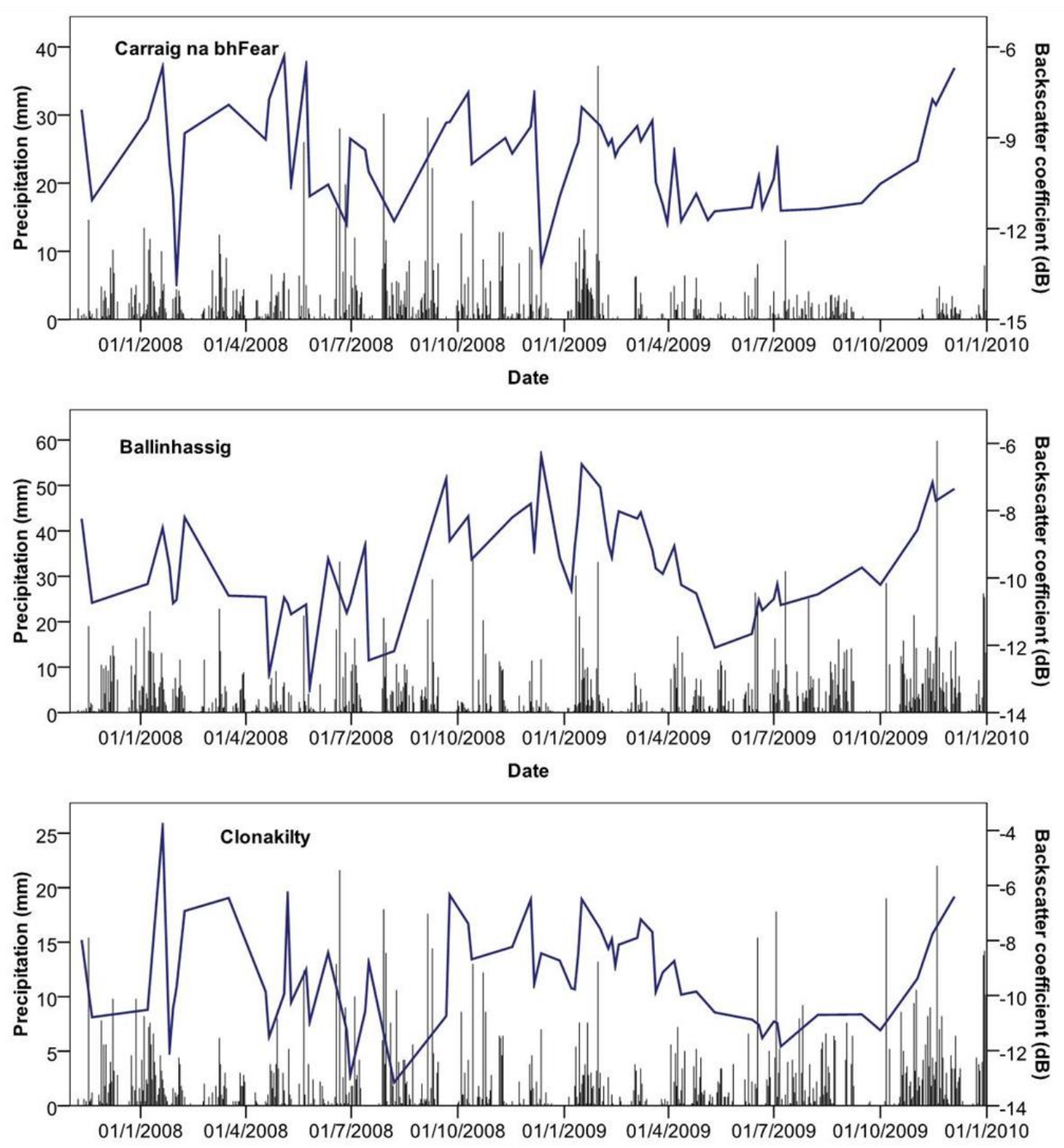
Figure 4
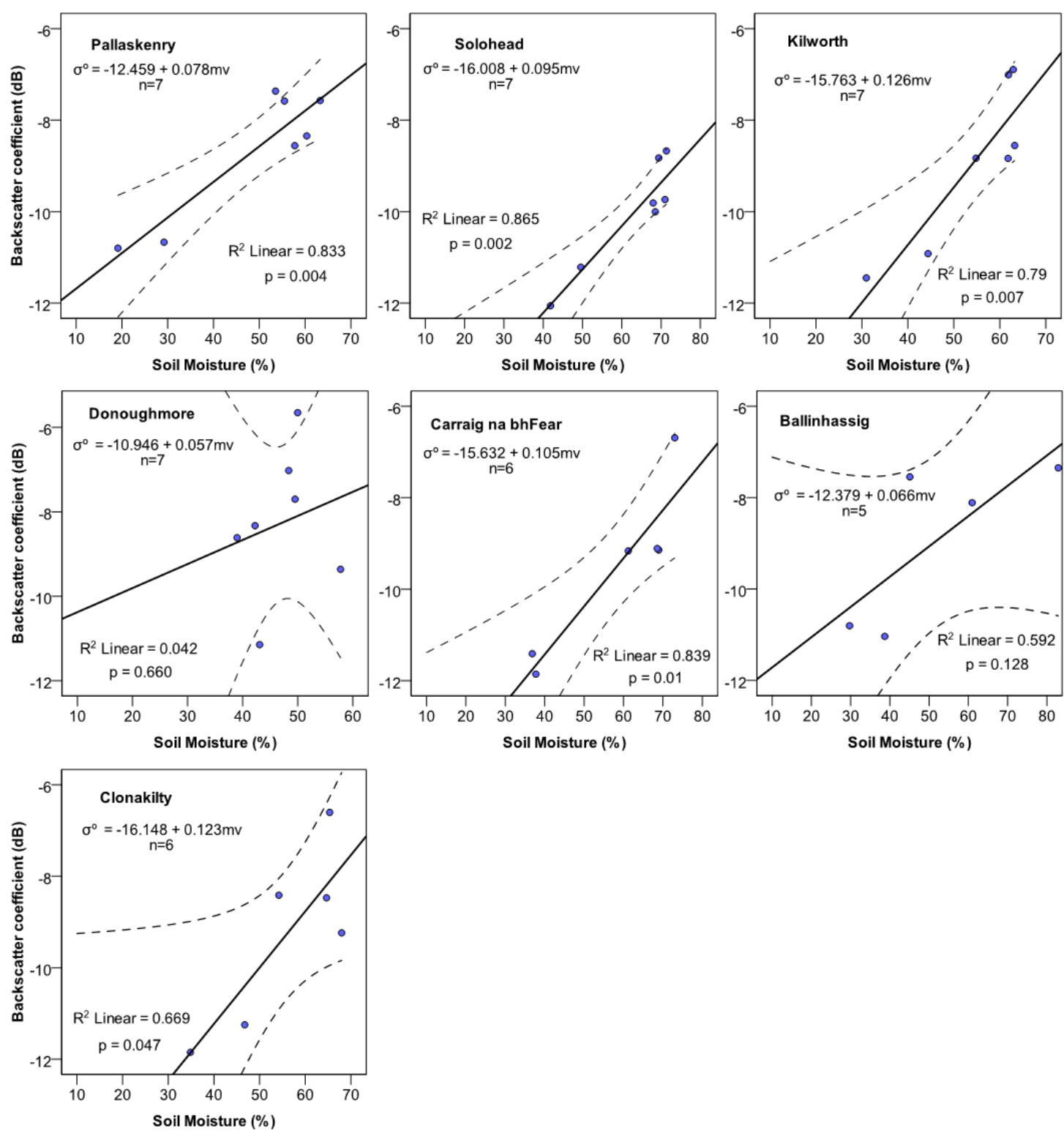
Figure 5
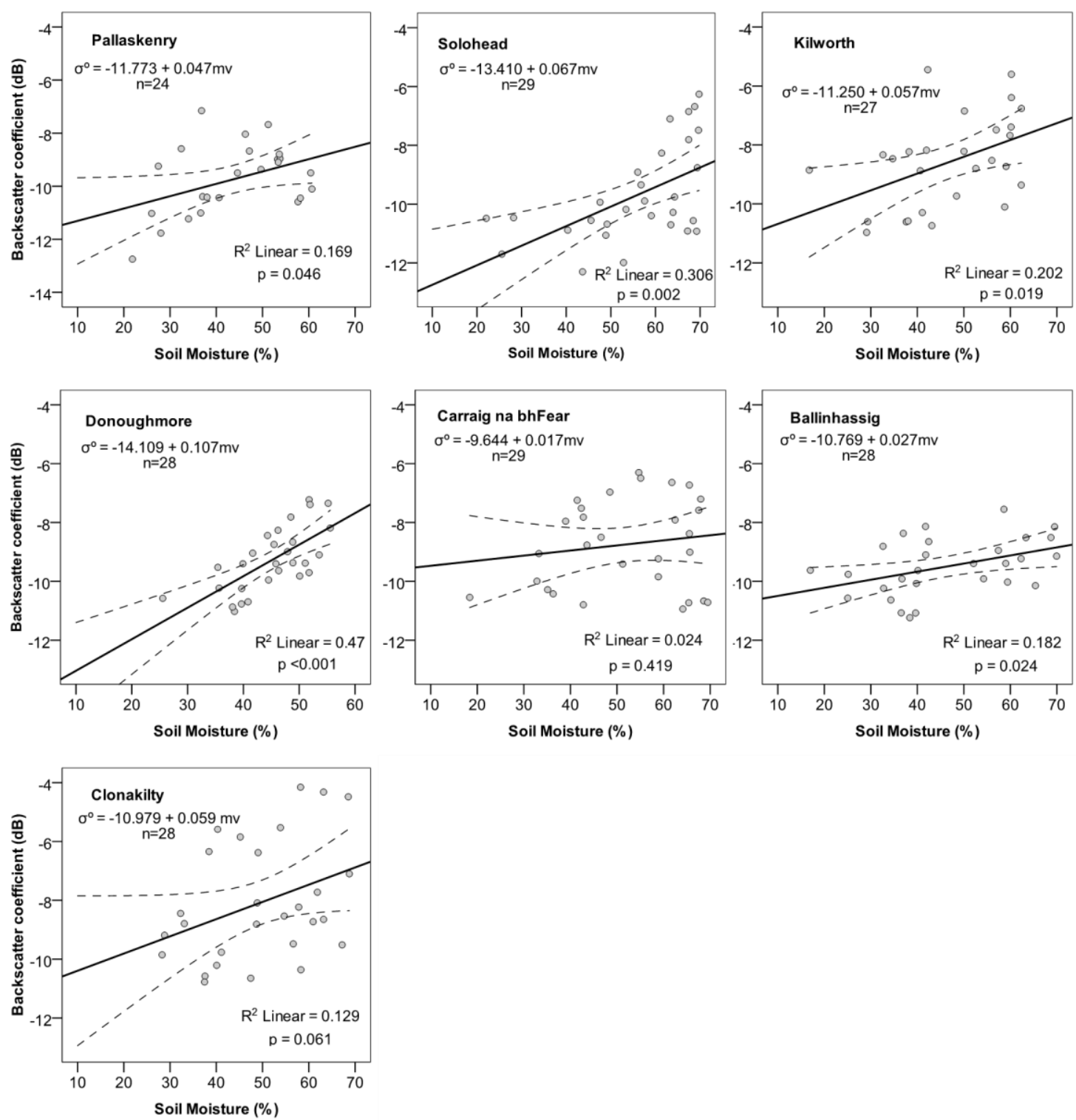


\section{Figure 6}
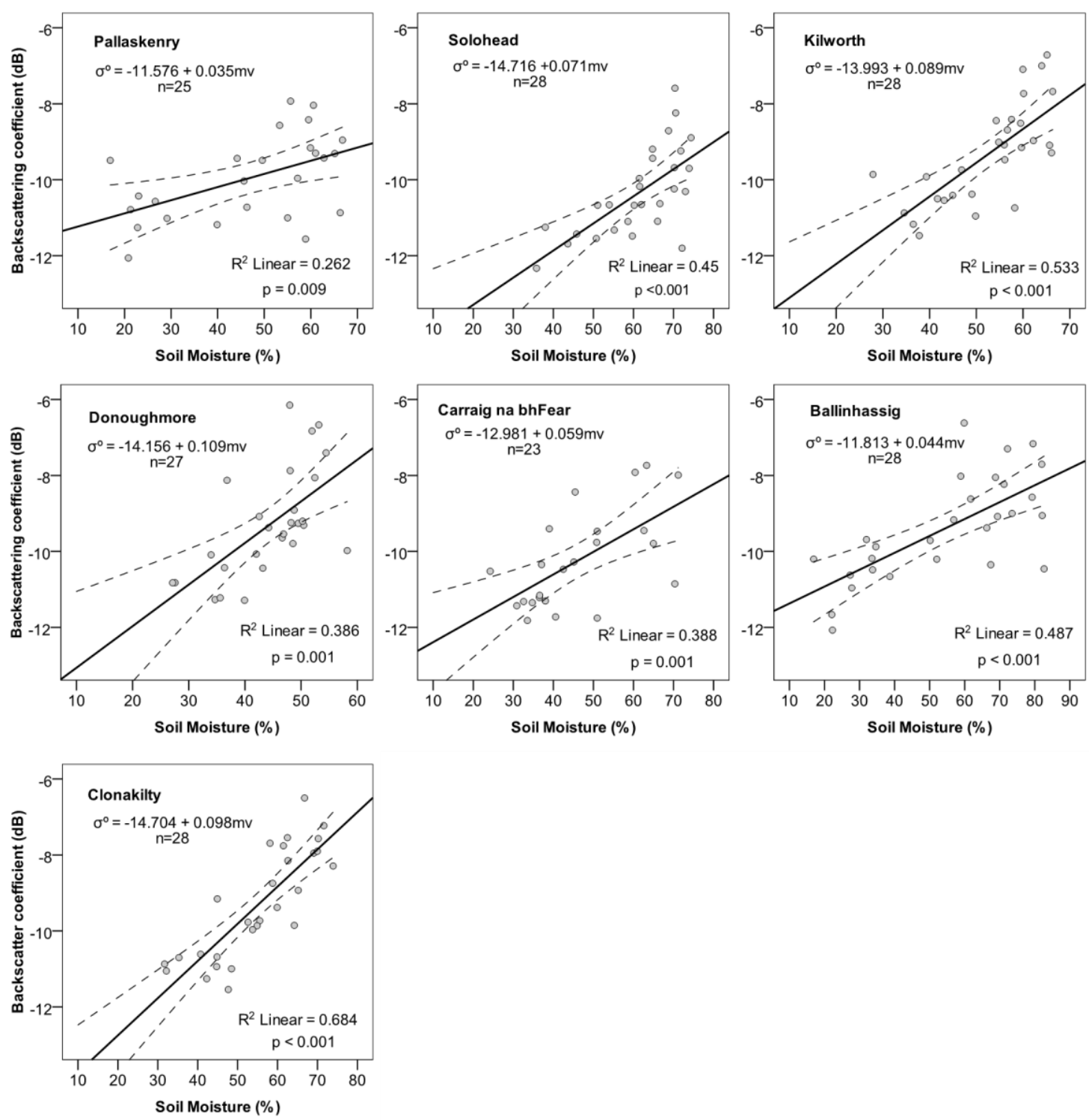
